\title{
Hypoxia upregulates hypoxia inducible factor (HIF)-3 $\alpha$ expression in lung epithelial cells: characterization and comparison with HIF-1 $\alpha$
}

\author{
Qi Fang $\mathrm{Li}^{1}$, Xiang Rui Wang ${ }^{1}$, Yue Wu Yang ${ }^{1}$, Han $\operatorname{Lin}^{1}$ \\ ${ }^{1}$ Department of Anesthesiology, Renji Hospital, Shanghai Second Medical University, 1630 Dongfang Road, Shanghai 200127, \\ China
}

The role of the hypoxia-inducible factor (HIF) subunits $1 \alpha$ and $2 \alpha$ in response to hypoxia is well established in lung epithelial cells, whereas little is known about HIF-3 $\alpha$ with respect to transcriptional and translational regulation by hypoxia. HIF-3 $\alpha$ and HIF-1 $\alpha$ are two similar but distinct basic helix-loop-helix-PAS proteins, which have been postulated to activate hypoxia responsive genes in response to hypoxia. Here, we used quantitative real time RT-PCR and immunoblotting to determine the activation of HIF- $3 \alpha$ vs. HIF- $1 \alpha$ by hypoxia. HIF-3 $\alpha$ was strongly induced by hypoxia ( $1 \%$ $\mathrm{O}_{2}$ ) both at the level of protein and mRNA due to an increase in protein stability and transcriptional activation, whereas HIF-1 $\alpha$ protein and mRNA levels enhanced transiently and then decreased because of a reduction in its mRNA stability in A549 cells, as measured on mRNA and protein levels. Interestingly, HIF-3 $\alpha$ and HIF-1 $\alpha$ exhibited strikingly similar responses to a variety of activating or inhibitory pharmacological agents. These results demonstrate that HIF-3 $\alpha$ is expressed abundantly in lung epithelial cells, and that the transcriptional induction of HIF-3 $\alpha$ plays an important role in the response to hypoxia in vitro. Our findings suggest that HIF-3 $\alpha$, as a member of the HIF system, is complementary rather than redundant to HIF-1 $\alpha$ induction in protection against hypoxic damage in alveolar epithelial cells.

Cell Research (2006) 16:548-558. doi:10.1038/sj.cr.7310072; published online 15 June 2006

Keywords: hypoxia inducible factor, alveolar epithelial type II cells, hypoxia, gene expression, in vitro

\section{Introduction}

Low cellular oxygen tension is seen in pathological conditions including ischemia [1], inflammation [2], hemorrhage [3] and neoplasm [4]. A variety of systemic and cellular responses for homeostatic adaptations are provoked under these hypoxic conditions, including erythropoiesis, vasodilatation, angiogenesis and glycolysis. Hypoxia activates the transcription of genes whose products mediate these responses [5]. Hypoxia inducible factor-1(HIF-1), a transcriptional factor expressed in many cells, is activated in response to hypoxia [6]. This heterodimeric transcrip-

Correspondence: Xiang Rui Wang

Tel: 86-21-50903239; Fax: 86-21-50903239

E-mail: xiangruiwang@yahoo.com.cn

Received 31 Aug 2005; revised 22 Mar 2006; accepted 4 Apr 2006; published online 15 Jun 2006 tional factor consists of two subunits, HIF-1 $\alpha$ and HIF-1 $\beta$. Both subunits are constitutively expressed and belong to a family of basic helix-loop-helix-Per-Arnt-Sim (bHLHPAS) transcriptional factors that are required both for DNA binding and for transactivation of an array of target genes. Whereas HIF-1 $\beta$, also termed the aryl hydrocarbon nuclear receptor translocator (ARNT), can heterodimerize with other proteins containing the bHLH-PAS domain [7]. HIF$1 \alpha$ is the specific and oxygen-regulated subunit of the HIF-1 complex and determines the level of HIF-1 activity $[8,9]$. Under normoxia, the HIF-1 $\alpha$ subunit is rapidly degraded by the ubiquitin-proteasome system, thus hampering the heterodimeric HIF-1 activity [10]. By contrast, under hypoxia or in the presence of iron chelators, the degradation of HIF- $1 \alpha$ is prevented $[7,11,12]$. As a result, this stabilization initiates a multi-step pathway of activation of HIF-1 $\alpha$ that includes hypoxia-dependent nuclear translocation and dimerization with ARNT to interact with hypoxia respon- 
sive element (HRE) of target genes such as erythropoietin (EPO) [13], vascular endothelial growth factor (VEGF) [14], inducible nitric-oxide synthase [15], heme oxygenase 1 [16], and so on. Taken together, it comes as no surprise that the HIF-dependent hypoxic response pathway plays a prominent role in mediating the consequences of many disease states, including cerebral and myocardial ischemia, pulmonary hypertension, and tumorigenesis [17].

Besides the well-established HIF- $1 \alpha$, two other members of the bHLH-PAS superfamily have also been described: HIF- $2 \alpha$, referred also to as endothelial PAS domain protein 1 or HIF-1 $\alpha$-like-factor (HLF), which bears functional resemblance to HIF-1 $\alpha$ regarding hypoxic stabilization and binding to ARNT [18], and lastly HIF-3 $\alpha$ [19]. HIF-2 $\alpha$ and HIF-3 $\alpha$ appear to be expressed in a cell-specific manner, when compared with the ubiquitously expressed HIF- $1 \alpha$. There has been long-term interest in distinguishing the roles of HIF- $1 \alpha$ and HIF- $2 \alpha$, HIF- $3 \alpha$. Although much has been learned about the role of HIF- $1 \alpha$ and HIF- $2 \alpha$ in activating the transcription of hypoxia-responsive genes, the mechanism by which HIF-3 $\alpha$ levels within cells are regulated by hypoxia is still poorly understood.

The presence of HIF- $1 \alpha$ and HIF- $2 \alpha$ in lung alveolar epithelial cells has been reported in separate studies, suggesting that the two isoforms are co-expressed $[20,21]$. The hypoxic induction of HIF- $2 \alpha$ has been demonstrated in vivo and in vitro in different organs under various conditions $[22,23]$. Very recently, the acute hypoxic induction of HIF-3 $\alpha$ has been demonstrated in lung, cerebral cortex, and hippocampus [24, 25], but these findings raise important questions as to whether HIF- $3 \alpha$ are regulated by the severity and duration of hypoxia in alveolar epithelial cells. Moreover, the mechanisms by which alveolar epithelial cells sense hypoxia have not been yet fully elucidated.

In this report, we investigated whether alveolar epithelial cells express HIF-3 $\alpha$ and compared the regulation of HIF-3 $\alpha$ and HIF- $1 \alpha$ by hypoxia. Our results indicated that, in lung alveolar epithelial cell, HIF-3 $\alpha$ is expressed abundantly and its characteristics of activation differ from that of HIF- $1 \alpha$ during sustained hypoxia. HIF- $3 \alpha$ also responds to a variety of pharmacological agents known to regulate HIF-1 $\alpha$, strongly suggesting that HIF- $3 \alpha$ be a member of the HIF system.

\section{Materials and Methods}

\section{Reagents and cell culture}

All reagents were purchased from Sigma (St. Louis, MO) or Invitrogen (Carlsbad, CA) unless otherwise specified.

Because obtaining primary type-II epithelial cells of sufficient purity from rat or human lung is difficult $>5 \%$ of alveolar macrophage contamination was not eliminated), A549 cells (American Type Culture Collection, Rockville, MD, USA), a pulmonary type-II epithelial cell line derived from an individual with alveolar cell carcinoma, were used. These cells retain many of the characteristics of normal type-II epithelial cells, such as surfactant production, cytoplasmic multilamellar inclusion bodies and cuboidal appearance [26]. Cells were grown in Kaighn's modified Ham's F-12 medium supplemented with $2 \mathrm{mM} \mathrm{L}$-glutamine, $1.5 \mathrm{~g} / 1$ sodium bicarbonate, $50 \mathrm{U} / \mathrm{ml}$ penicillin, $50 \mu \mathrm{g} / \mathrm{ml}$ streptomycin, and $10 \%$ fetal bovine serum.

\section{Exposure to hypoxia}

Hypoxia and normoxia protocol was set up as described previously [21]. Briefly, on the day of the experiment, the medium was replaced with a thin layer of fresh medium $\left(0.15 \mathrm{ml} / \mathrm{cm}^{2}\right)$ with $10 \%$ fetal calf serum to decrease the diffusion distance of the ambient gas. Culture dishes were then placed in a humidified airtight incubator with inflow and outflow valves, and the hypoxic gas mixture $\left(1 \% \mathrm{O}_{2}\right.$, $5 \% \mathrm{CO}_{2}$, and balance $\mathrm{N}_{2}$ ) was delivered at $10 \mathrm{l} / \mathrm{min}$ for $25 \mathrm{~min}$. The airtight incubator was kept at $37^{\circ} \mathrm{C}$ for preset time periods whereas normoxic cells were placed at $37^{\circ} \mathrm{C}$ in a $21 \% \mathrm{O}_{2}, 5 \% \mathrm{CO}_{2}$, and $74 \%$ $\mathrm{N}_{2}$ humidified incubator until harvest.

\section{Protein extraction and immunoblot analysis}

Whole cell extracts and nuclear cell extracts were prepared as described previously [27]. A total of $100 \mu \mathrm{g}$ of protein was loaded on to a $10 \% \mathrm{SDS} /$ polyacrylamide gel and after electrophoresis it was blotted on to nitrocellulose membranes. The primary rabbit anti-human HIF-3 $\alpha$ (ab10134, Abcam Ltd.UK) and HIF-1 $\alpha$ (07-628, Upstate, USA) polyclonal antibodies were used at 1:400 and 1:1 000 dilution respectively, and anti- $\beta$-actin monoclonal antibody (Sigma) was used at 1:4 000 dilution. The anti-rabbit IgG secondary antibody (KPL, USA) was used at 1:2000 dilution, and the signal was analyzed by enhanced chemiluminescence (Chemicon). Under these conditions HIF- $3 \alpha$ appeared as a band of about $60 \mathrm{kDa}$ and HIF- $1 \alpha$ as a band of about $100 \mathrm{kDa}$. The abundance of HIF-3 $\alpha$ and HIF-1 $\alpha$ proteins was normalized to $\beta$-actin using software Quantity One-4.2.3.

\section{RNA isolation and cDNA synthesis}

Cells were harvested and RNA was isolated with TRIzol (Invitrogen). First-strand cDNA was synthesized from $1 \mu \mathrm{g}$ of total RNA in the presence of $5 \times \mathrm{RT}$ buffer, $2 \mu \mathrm{L}$ of $10 \mathrm{mM}$ dNTPs, $1 \mu \mathrm{L}$ of oligo-(dT) 18 primer, $0.5 \mu \mathrm{L}$ RNasin, $2 \mu \mathrm{L}$ Moloney murine leukemia virus reverse transcriptase (MMLV) (Gibico, BRL), and volume for adjustment to $20 \mu \mathrm{L}$ according to the manufacturer's instruction.

\section{Determination of $m R N A$ levels by quantitative real-time PCR}

Quantitative real-time PCR estimation of mRNA levels was performed as described previously [28]. Real-time quantitative PCR was performed by using SYBR green I as fluorescent dye (DRR041A,TaKaRa Biotechnology, China). Primers were obtained from Shanghai Sangon Biological Engineering \& Technology and Service Co. Ltd (Table 1). To ensure integrity and identity of the mRNA species, we sent the real time PCR products to biological company for sequencing, only when the products were consistent with the sequences of Gene bank, we used the primers for subsequent analysis. Amplification and detection were carried out by using an ABI PRISM 7700 detection system (Applied Biosystems) as following: 1 cycle at $95^{\circ} \mathrm{C}$ for $10 \mathrm{~s}, 40$ cycles at $95^{\circ} \mathrm{C}$ for $5 \mathrm{~s}$, and 60 ${ }^{\circ} \mathrm{C}$ for $30 \mathrm{~s}$. Real time PCR was performed in triplicate reactions with $20 \mathrm{ng}$ of cDNA in a final volume of $10 \mu \mathrm{L}$ containing $1 \times$ SYBR 
Table 1 Nucleotide sequences of PCR primers used in real-time quantitative RT-PCR

\begin{tabular}{lllll}
\hline Primer & Orientation & Sequence & PCR product size(bp) & Gene bank Accession No. \\
\hline HIF-1 $\alpha$ & sense & 5'-CCAGCAGACTCAAATACAAGAACC-3' & 138 & NM_001530 \\
& antisense & 5'-TGTATGTGGGTAGGAGATGGAGAT-3' & & NM_152794 \\
HIF-3 $\alpha$ & sense & 5'-TGGAGCTGCTGGGAGTGAGA-3' & 158 & NM_001101 \\
& antisense & 5'-GGGCTCATTCAGGTTCAGGAGT-3' & 353 & \\
$\beta$-actin & sense & 5'-GCTCGTCGTCGACAACGGCTC-3' & \\
& antisense & 5'-CAAACATGATCTGGGTCATCTTCTC-3' & & 5. \\
\hline
\end{tabular}

Green Master Mix and $200 \mathrm{nM} / \mathrm{L}$ of both primers. Results were normalized to the housekeeping gene $\beta$-actin for the study of transcriptional activity and mRNA half-life. To compare the expression levels among different samples, the relative expression of mRNA levels was calculated using the comparative delta $\mathrm{C}_{\mathrm{T}}$ (threshold cycle number) method as described previously [29]. Briefly, the following formula was used: $2^{-\Delta \Delta C_{T}}$, where $\Delta \mathrm{C}_{\mathrm{T}}$ is the difference in $\mathrm{C}_{\mathrm{T}}$ between the gene of interest and $\beta$-actin, and $\Delta \Delta \mathrm{C}_{\mathrm{T}}$ for the sample $=\Delta \mathrm{C}_{\mathrm{T}}$ for the actual sample- $\Delta \mathrm{C}_{\mathrm{T}}$ of the lowest expression sample. This calculation method requires that the efficiency of the target amplification and the reference amplification are approximately equal. All PCR efficiencies are measured and found to be $>90 \%$. In addition, product purity was confirmed by dissociation curve analysis and agarose gel electrophoresis.

\section{Measurements of mRNA Half-life}

A549 cells were grown in medium with or without $\mathrm{CoCl}_{2}(250$ $\mu \mathrm{M}$ ) for $6 \mathrm{~h}$. 5,6-Dichlorobenzimidazole 1- $\beta$-D-ribofuranoside (DRB; $65 \mu \mathrm{M})$ was then added to block transcription. In the $\mathrm{CoCl}_{2}$-treated cells, supplemental $\mathrm{CoCl}_{2}$ was added with the transcription inhibitor to keep the $\mathrm{CoCl}_{2}$ concentration at $250 \mu \mathrm{M}$. Cells were harvested for RNA at $0,0.5,1.0,1.5,2.0,4.0$ and $6.0 \mathrm{~h}$ after the addition of the transcription inhibitor. mRNA half-life was calculated from linear regression fitting curve as the time when the value decreased by half.

\section{Inhibition of ongoing transcription and ongoing protein synthesis}

To verify whether ongoing transcription is essential for the hypoxic regulation of HIF-3 $\alpha$ mRNA and compare with HIF- $1 \alpha$, the medium was replaced with DRB $(65 \mu \mathrm{M})$-containing medium. Two hours after this treatment, cells were incubated with gas containing $1 \%$ or $21 \% \mathrm{O}_{2}$ for $6 \mathrm{~h}$. To elucidate the necessity of ongoing protein synthesis for HIF- $3 \alpha$ mRNA regulation and compared with HIF-1 $\alpha$, the medium was replaced with cycloheximide (CHX, 100 $\mu \mathrm{M})$-containing medium and incubated with gas containing $1 \%$ or $21 \% \mathrm{O}_{2}$ for $6 \mathrm{~h}$.

\section{Statistical analysis}

All data are presented as mean \pm S.D. with $n=3 \sim 5$ in each group and are expressed as the ratio compared with the conditions of the normoxic control. For inter-group comparison, one-way analyses of variance (one-way ANOVA) were performed, and the difference was analyzed with S-N-K test as a post-hoc analysis. To evaluate whether HIF- $\alpha$ mRNA regulation depended on ongoing transcription or ongoing protein synthesis, two-way analyses of variance (2-way ANOVA) were performed. Statistical significance was defined as $P<0.05$
A

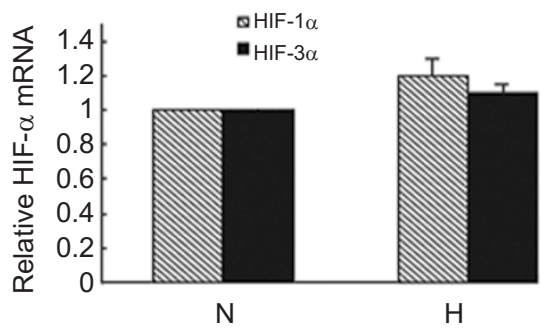

B

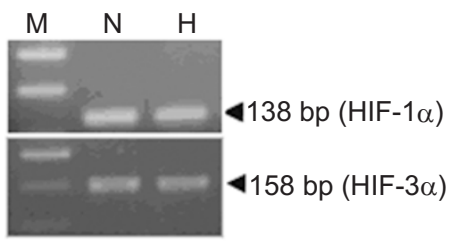

C

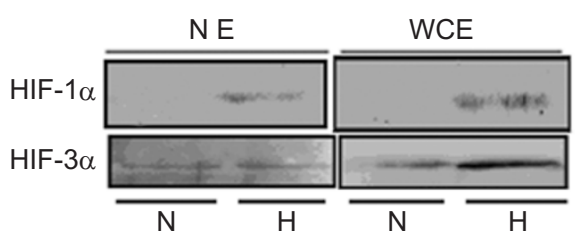

Figure 1 Analysis of HIF-3 $\alpha$ and HIF- $1 \alpha$ expression during normoxia (N; 21\% $\left.\mathrm{O}_{2}\right)$ and acute hypoxia $\left(\mathrm{H} ; 2 \mathrm{~h}, 1 \% \mathrm{O}_{2}\right)$. (A) HIF-3 $\alpha$ and HIF- $1 \alpha$ mRNAs related to housekeeping gene $\beta$-actin were analyzed by real time RT-PCR. Value determined after culture of cells in normoxic conditions was set at 1 . Values are mean \pm S.D. of three different experiments. $P>0.05$ versus $21 \% \mathrm{O}_{2}$. (B) Typical amplified cDNA fragments after 40 cycles of real time PCR during normoxia and acute hypoxia were visualized by agarose gel eletrophoresis to demonstrate specificity of amplification. Bands resulting from gel electrophoresis were not utilized for mRNA quantification. $\mathrm{M}$ denotes a $50 \mathrm{bp}$ DNA ladder with a brighter band at $200 \mathrm{bp}$. (C) A549 cells were exposed to normoxic or hypoxic conditions for $2 \mathrm{~h}$ prior to preparation of whole cell (WCE) or nuclear (NE) extracts and immunoblot analysis. 


\section{Results}

$H I F-3 \alpha$ and HIF-1 $\alpha$ expression in lung epithelial cells during normoxia and acute hypoxia

By quantitative real time PCR and agarose gel electrophoresis, normoxic mRNA levels of HIF- $3 \alpha$ and HIF- $1 \alpha$ were determined in A549 cells. As shown in Figure 1A and $1 \mathrm{~B}, \mathrm{HIF}-3 \alpha$ but not HIF- $1 \alpha$ were scarcely expressed in unstimulated cells $\left(\mathrm{C}_{\mathrm{T}}\right.$ values were $30.63 \pm 0.57$ and $26.76 \pm 0.32$ respectively). Amplification products for $\beta$-actin were traceable in all samples analyzed, which confirms the integrity of the mRNA. When reverse transcriptase was omitted during cDNA synthesis, no amplification was detected, indicating the absence of genomic DNA or contamination (data not shown). The mRNA expression patterns were paralleled by results of immunoblotting. The mRNA and protein levels of $\beta$-actin were not systemically affected by treatments (in particular hypoxia) applied in our experiment (data not shown), which agreed with previous studies $[21,30]$. The protein levels of HIF$1 \alpha$ were fairly detectable in both whole cell and nuclear extracts during normoxia. In contrast, a visible presence of HIF-3 $\alpha$ protein was observed in both whole cell and nuclear extracts (Figure 1C). To determine if HIF-3 $\alpha$ protein levels were induced by hypoxia and to compare the response with those of HIF-1 $\alpha$ in lung epithelial cells, whole cell and nuclear extracts were prepared following parallel normoxic and hypoxic incubation. Exposure to hypoxia ( $1 \%$ ) for $2 \mathrm{~h}$ induced HIF-3 $\alpha$ and HIF- $1 \alpha$ protein accumulation (Figure 1C).

The hypoxic induction of HIF-3 $\alpha$ and HIF- $1 \alpha$ proteins was dependent on the duration of exposure to hypoxia. Both HIF- $3 \alpha$ and HIF- $1 \alpha$ protein increased rapidly within 30 min of exposure to $1 \%$ oxygen and increased further with a longer exposure to hypoxia, indicating the stabilization of proteins by hypoxia (Figure 2A). The induction also depended on cell density. The basal levels of both proteins significantly reduced when cells were cultured at lower density (Figure 2B). The hypoxic induction of HIF-3 $\alpha$ and HIF$1 \alpha$ proteins was also dependent on the $\mathrm{O}_{2}$ concentration. HIF- $3 \alpha$ and HIF- $1 \alpha$ proteins were significantly induced when cells were exposed to $\mathrm{O}_{2}$ concentrations below $5 \%$, as compared to those under normoxia, and the increases reached the peak at $3 \%$ and $1 \%$ oxygen, respectively. Interestingly, the response to 5\% oxygen appeared to result in a greater increase in HIF- $3 \alpha$ compared to HIF-1 $\alpha$ (Figure 2C). To investigate whether increases in HIF- $\alpha$ protein levels were related to post-transcriptional or post-translational changes, HIF- $\alpha$ mRNA levels were also evaluated after a 2-h incubation in normoxic or hypoxic conditions. Hypoxia did not change HIF- $3 \alpha$ and HIF- $1 \alpha$ mRNA levels (Figure 1A and 1B), suggesting that acute hypoxia-induced increases in HIF-3 $\alpha$ and HIF- $1 \alpha$ proteins are likely due to translational or post-translational changes.
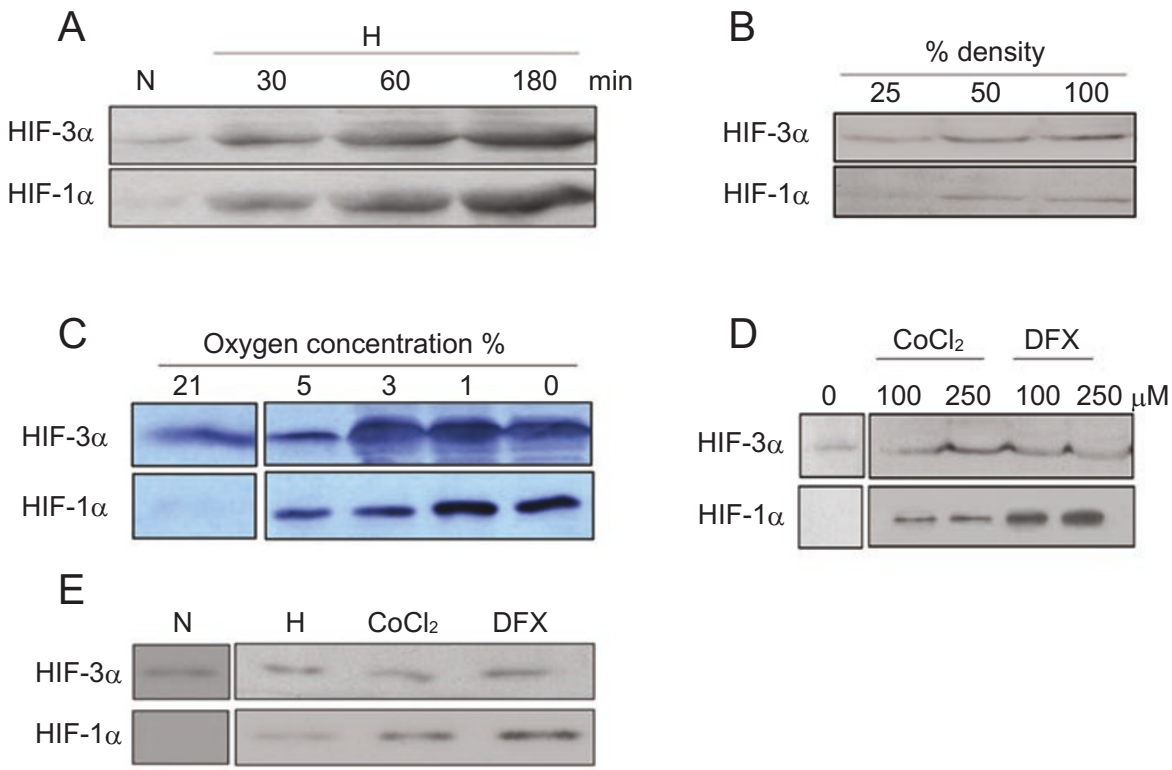

Figure 2 Characterization of induction of HIF- $3 \alpha$ and HIF- $1 \alpha$ by hypoxia in A549 cells. (A) Cells were exposed to hypoxia ( $1 \% \mathrm{O}_{2}$ ) for 30 to $180 \mathrm{~min}$. (B) Cells were seeded at different densities and cultured under normoxic conditions $\left(21 \% \mathrm{O}_{2}\right)$ for $6 \mathrm{~h}$. (C) Cells were exposed to different oxygen concentrations for $6 \mathrm{~h}$. (D) Cells exposed to normoxia were incubated with $100 \mu \mathrm{M}$ or $250 \mu \mathrm{M}$ $\mathrm{CoCl}_{2} / 250 \mu \mathrm{M}$ DFX for $6 \mathrm{~h}$. (E) Cells were subjected to hypoxia $\left(1 \% \mathrm{O}_{2}\right)$ or treated with $250 \mu \mathrm{M} \mathrm{CoCl}_{2}$ or $250 \mu \mathrm{M} \mathrm{DFX} \mathrm{for} 6 \mathrm{~h}$ prior to whole cell extraction and immunoblot analysis. 
Time kinetics of HIF-3 $\alpha$ and HIF-1 $\alpha$ induction in lung epithelial cells during hypoxia

To evaluate the kinetics of hypoxic induction of HIF$3 \alpha$ and HIF- $1 \alpha$ in lung epithelial cells, A549 cells were exposed to hypoxia $(1 \%)$ or $\mathrm{CoCl}_{2}(250 \mu \mathrm{M})$ from $2 \mathrm{~h}$ to $16 \mathrm{~h}$. Following the rapid induction of the HIF-1 $\alpha$ protein observed at $2 \mathrm{~h}$ of hypoxia, HIF-1 $\alpha$ protein levels showed a continuously increasing expression for up to $4 \mathrm{~h}$ of hypoxia, but diminished after $8 \mathrm{~h}$ and returned to basal levels after $16 \mathrm{~h}$ of hypoxia. In contrast, the hypoxic induction of the HIF- $3 \alpha$ protein reached the peak at $8 \mathrm{~h}$ and remained at the peak level at $16 \mathrm{~h}$ (Figure 3A). Similar results were obtained with $\mathrm{CoCl}_{2}$ treatment (Figure 3B). Interestingly, HIF-3 $\alpha$ and HIF- $1 \alpha$ mRNA changes were also differentially regulated by sustained hypoxia. While $2 \mathrm{~h}$ of hypoxia did not affect either HIF-3 $\alpha$ or HIF- $1 \alpha$ mRNA levels, sustained hypoxia induced dramatic and opposite changes in HIF-3 $\alpha$ and HIF-1 $\alpha$ mRNA levels. HIF-1 $\alpha$ mRNA levels dramatically decreased from 4 to $16 \mathrm{~h}$ of hypoxia (Figure $4 \mathrm{~B}$ ), whereas HIF-3 $\alpha$ mRNA levels enhanced significantly at the same time points (Figure 4A). Quantification of HIF-3 $\alpha$ mRNA levels normalized to $\beta$-actin mRNA levels showed a 7.7-

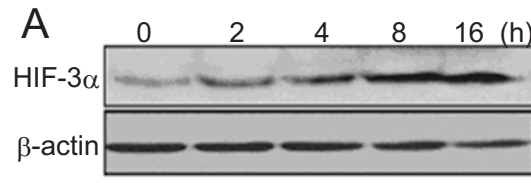

$\mathrm{B}$

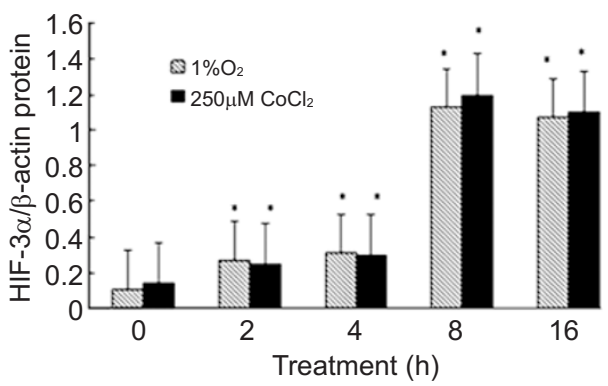

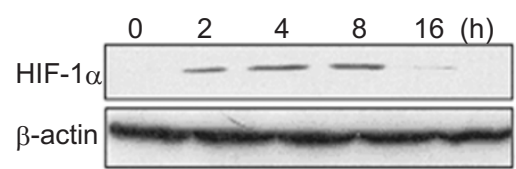

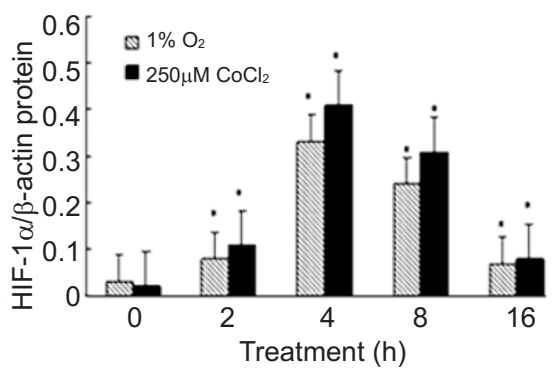

Figure 3 Time course of hypoxia and cobalt chloride on protein levels of HIF-3 $\alpha$ and HIF-1 $\alpha$ in A549 cells. Cells were exposed to normoxia $\left(21 \% \mathrm{O}_{2}\right)$ in the absence or presence of $250 \mu \mathrm{M} \mathrm{CoCl}_{2}$ or to hypoxia $\left(1 \% \mathrm{O}_{2}\right)$ for various hours. At the end of incubation, protein levels were determined in whole cell extracts by immunoblot analysis. (A) A representative gel showing the effects of hypoxia on HIF-3 $\alpha$ and HIF-1 $\alpha$ protein levels. (B) Summarized data showing the protein levels of HIF-3 $\alpha$ and HIF-1 $\alpha$ when treated with different stimuli. The protein levels of HIF- $3 \alpha$ and HIF- $1 \alpha$ were normalized to the $\beta$-actin protein. Data are presented as mean \pm S. D. of three different experiments. ${ }^{*}, P<0.01$ vs. $21 \% \mathrm{O}_{2}$.
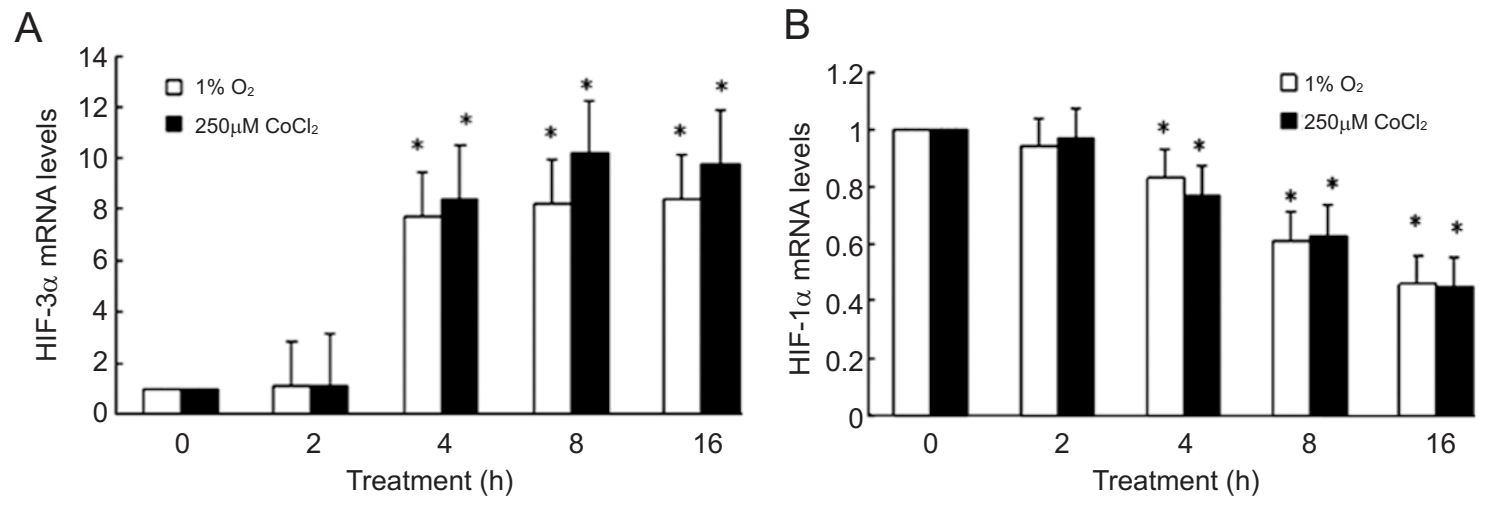

Figure 4 Effects of hypoxia and cobalt chloride on HIF-3 $\alpha$ (A) and HIF-1 $\alpha$ (B) mRNA levels in A549 cells. Normoxic cells were incubated with $1 \% \mathrm{O}_{2}$ or $250 \mu \mathrm{M} \mathrm{CoCl}_{2}$ for $2,4,8$ and $16 \mathrm{~h}$. At the end of incubation, HIF- $3 \alpha$ and HIF- $1 \alpha$ mRNAs related to housekeeping gene $\beta$-actin mRNA were analyzed by real time RT-PCR. Value obtained in untreated cells under a normoxic condition was set at 1 . Values are mean \pm S.D. of three different experiments. *, $P<0.01$ vs. $21 \% \mathrm{O}_{2}$. 
fold induction after $8 \mathrm{~h}$ of hypoxic stimulation. Similar results were obtained with $\mathrm{CoCl}_{2}$ treatment (Figure 4).

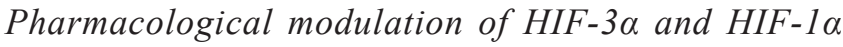 protein levels}

Pharmacological approaches that imitate hypoxic responses have gained important insights on the mechanism of oxygen sensing and/or signal transduction pathway underlying HIF- $1 \alpha$ and HIF- $2 \alpha$ activation. To further compare the regulation of HIF- $3 \alpha$ with HIF-1 $\alpha$, we observed the response of each protein to several of these approaches. The transition metal $\mathrm{CoCl}_{2}$ and the iron chelator desferrioxamine (DFX) have been shown to mimic hypoxic state in several hypoxia-responsive genes [30]. $\mathrm{CoCl}_{2}$ is thought to substitute for iron in the porphyrin ring of the $\mathrm{O}_{2}$ sensor, binding $\mathrm{O}_{2}$ with less affinity, thereby locking it in a deoxygenated conformation. In $\mathrm{A} 549$ cells, $\mathrm{CoCl}_{2}$ induced a concentration-dependent increase in HIF- $3 \alpha$ and HIF- $1 \alpha$ levels (Figure 2D). $\mathrm{CoCl}_{2}$ at $100 \mu \mathrm{M}$ significantly increased both proteins and $\mathrm{CoCl}_{2}$ at $250 \mu \mathrm{M}$ increased them even further. Similar results with DFX were also obtained (for HIF-3 $\alpha$ : $0.36 \pm 0.01$ vs. $0.42 \pm 0.04, P<0.05$, quantified by densitometric analysis). Figure $2 \mathrm{E}$ shows that HIF-3 $\alpha$ and HIF-1 $\alpha$ expression in normoxic cells was increased to a similar level by DFX $(250 \mu \mathrm{M}), \mathrm{CoCl}_{2}(250 \mu \mathrm{M})$ and hypoxia (1\%) for the same period of time $(6 \mathrm{~h})$. Because mitochondrial reactive oxygen species are reported to be regulators of HIF- $1 \alpha$ and HIF- $2 \alpha$ stabilization [21], we then examined the effects of mitochondrial reactive oxygen species inhibitors on HIF-3 $\alpha$ proteins levels. Pretreatment with mitochondrial reactive oxygen species inhibitors such as rotenone, diphenyleneiodonium and myxothiazol partially reduced basal and hypoxia-induced HIF- $3 \alpha$ and HIF- $1 \alpha$ accumulation (Figure 5A and 5B). These results suggest that HIF- $3 \alpha$ protein stabilization also requires mitochondrial respiratory chain.

\section{Effect of DRB on hypoxia-induced HIF-3a and HIF-1a transcription rate and $m R N A$ stability}

Induction of HIF- $\alpha$ mRNA expression during hypoxia could result from an increased gene transcription, increased mRNA stability, or both. To investigate the mechanism of hypoxia-induced increase of HIF-3 $\alpha$ mRNA, A549 cells were treated with DRB, a potent inhibitor of transcription, for $2 \mathrm{~h}$ before hypoxic exposure (1\%) for $6 \mathrm{~h}$. DRB abolished the hypoxia-induced increase in HIF-3 $\alpha$ mRNA (Figure 6A), suggesting that the active RNA transcription was required for this effect. To test whether hypoxia was associated with the change in mRNA stability, A549 cells were cultured in the normoxic medium or $\mathrm{CoCl}_{2}$-containing medium, $\mathrm{CoCl}_{2}$-treated cells were used instead of hypoxic cells to avoid the issue that reoxygenation would occurred
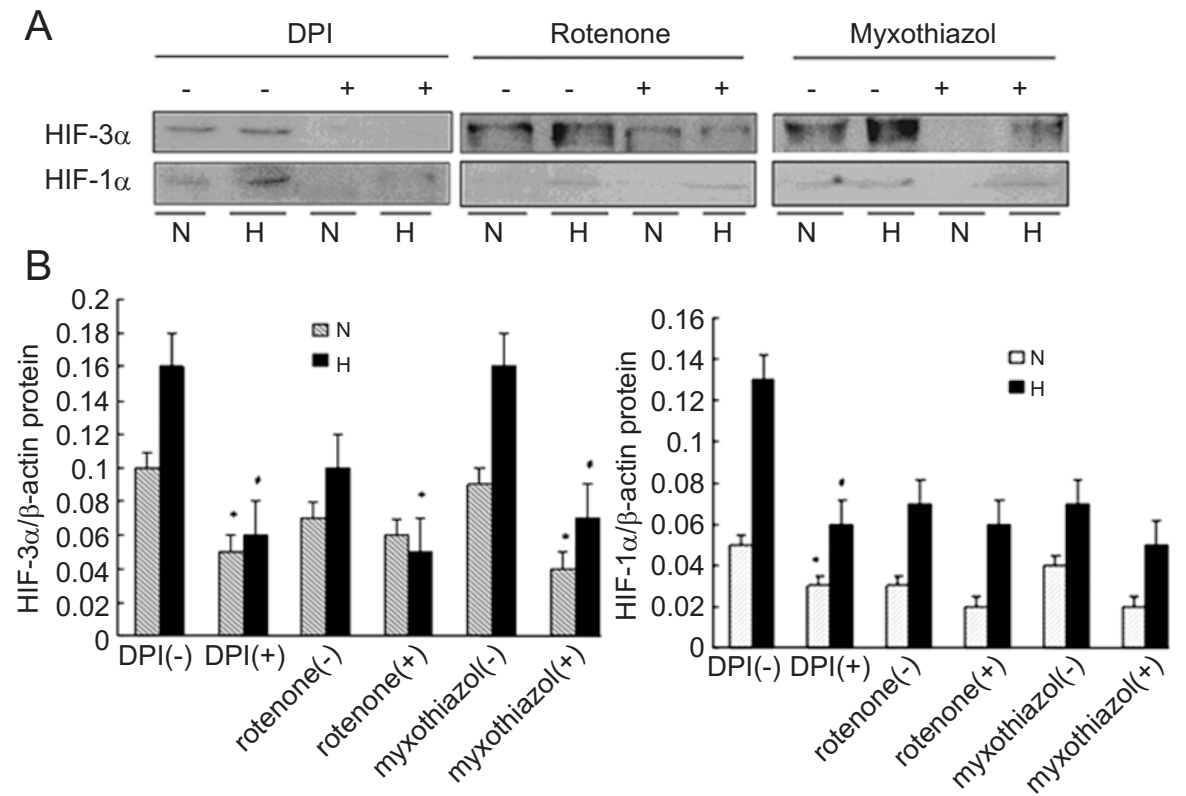

Figure 5 Effects of inhibitors of reactive oxygen species on HIF-3 $\alpha$ and HIF-1 $\alpha$ protein levels in A549 cells. Cells were exposed to normoxia $\left(\mathrm{N}: 21 \% \mathrm{O}_{2}\right)$ or hypoxia $\left(\mathrm{H}: 1 \% \mathrm{O}_{2}\right)$ for $6 \mathrm{~h}$ in the absence $(-)$ or presence $(+)$ of diphenyleneiodonium (DPI), rotenone or myxothiazol. Each experiment was repeated three times and similar results were observed. (A) Representative blots of whole cell extracts, (B) summarized data showing the levels of HIF- $3 \alpha$ and HIF- $1 \alpha$ protein when treated with different stimuli, $* P<0.05$, \# $P<0.01$ vs. the values obtained without inhibitors of reactive oxygen species. 

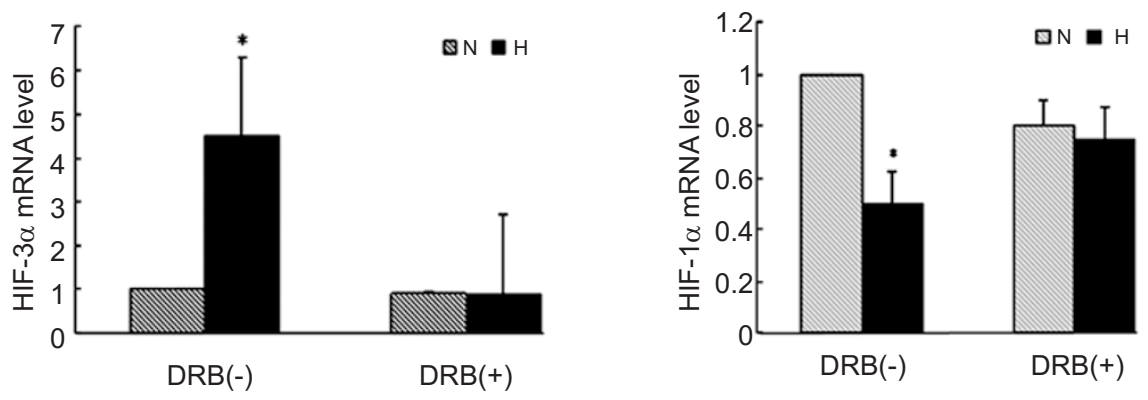

Figure 6 Effects of hypoxia on mRNA transcription rate in A549 cells. Cells were incubated with (+) or without (-) $65 \mu \mathrm{M}$ DRB for $2 \mathrm{~h}$ and then exposed to normoxia $\left(\mathrm{N} ; 21 \% \mathrm{O}_{2}\right)$ or hypoxia $\left(\mathrm{H} ; 1 \% \mathrm{O}_{2}\right)$ for $6 \mathrm{~h}$. HIF- $\alpha$ mRNA was normalized to corresponding $\beta$-actin. mRNA was analyzed by real time RT-PCR. Value determined at normoxia without DRB was set at 1 . Data are presented as mean \pm S.D. of four different experiments. ${ }^{*} P<0.01$ vs. $21 \% \mathrm{O}_{2}$, indicating a significant interaction between the $\mathrm{O}_{2}$ concentration and DRB treatment.

A

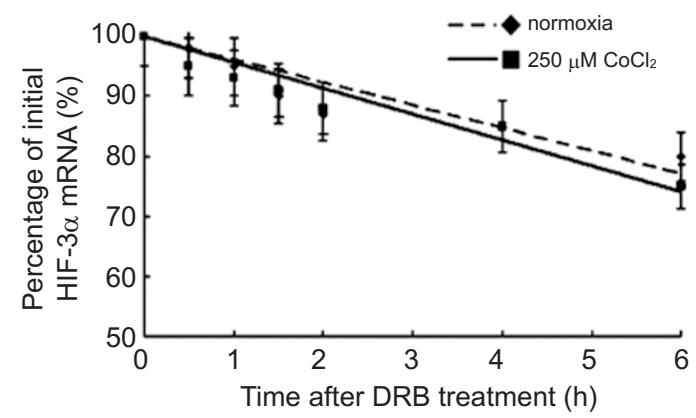

B

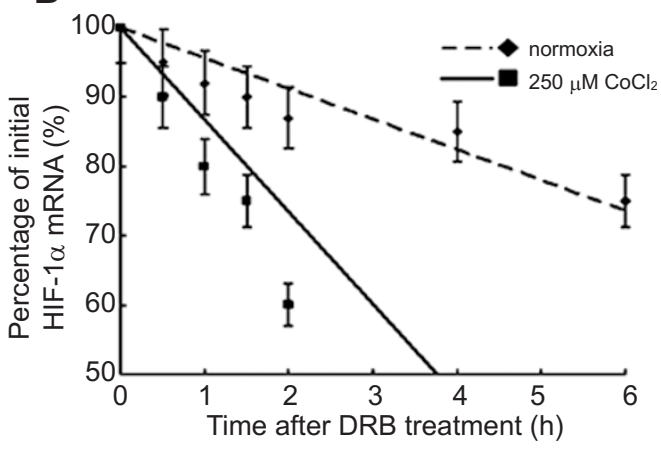

Figure 7 Effects of cobalt chloride on HIF- $\alpha$ mRNA stability in A549 cells. Cells were pretreated with or without $250 \mu \mathrm{M} \mathrm{CoCl}{ }_{2}$ for $6 \mathrm{~h}$, followed by treatment with $65 \mu \mathrm{M}$ DRB and harvested at various time periods. HIF- $\alpha$ mRNA was normalized to corresponding $\beta$-actin mRNA. mRNA was analyzed by real time RT-PCR. Value determined at time 0 was set as $100 \%$. Data are presented as mean \pm S.D. of three different experiments. There was significant difference between slopes for HIF-1 $\alpha$ (B) but not for HIF-3 $\alpha$ (A).

when DRB was added. Figure 7A shows that $\mathrm{CoCl}_{2}$-treatment did not alter the half-life of HIF-3 $\alpha$ mRNA compared with normoxia ( $11.6 \mathrm{~h}$ vs. $13.2 \mathrm{~h}$ ). In a similar experiment, hypoxia did not alter the $\beta$-actin mRNA half-life (data not shown). Thus, our result indicates that the elevated mRNA levels in response to hypoxia are not likely due to changes in mRNA turnover but the reflection of an enhanced transcription. In contrast to HIF- $3 \alpha, \mathrm{CoCl}_{2}$-treatment $(250 \mu \mathrm{M})$ dramatically decreased the half-life of HIF- $1 \alpha$ mRNA compared with normoxia ( $3.8 \mathrm{~h}$ vs. $11.4 \mathrm{~h}$ ) and DRB abolished the decrease in HIF-1 $\alpha$ mRNA levels induced by hypoxia (Figure 6B and Figure 7B). These results suggest that a fall in the HIF- $1 \alpha$ mRNA levels during sustained hypoxia was related mainly to decreased mRNA stability.
Implication of translational activity in the hypoxic regulation of HIF-3 $\alpha$ and HIF-1 $\alpha$ mRNA

To examine the possible involvement of newly synthesized proteins in hypoxia-induced regulation of HIF-3 $\alpha$ and HIF-1 $\alpha$, cells were pretreated with cycloheximide (CHX), an inhibitor of translation, before hypoxic exposure. These results are summarized in Figure 8. CHX completely prevented the decrease in HIF- $1 \alpha$ mRNA and the increase in HIF-3 $\alpha$ mRNA by hypoxia, suggesting that de novo protein synthesis is required for the regulation of HIF- $\alpha$ mRNA.

\section{Discussion}

The third $\alpha$-class of HIF subunit was first isolated in 
A

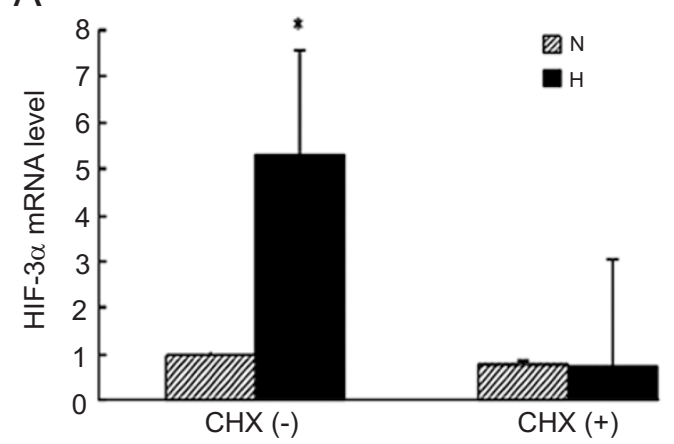

B

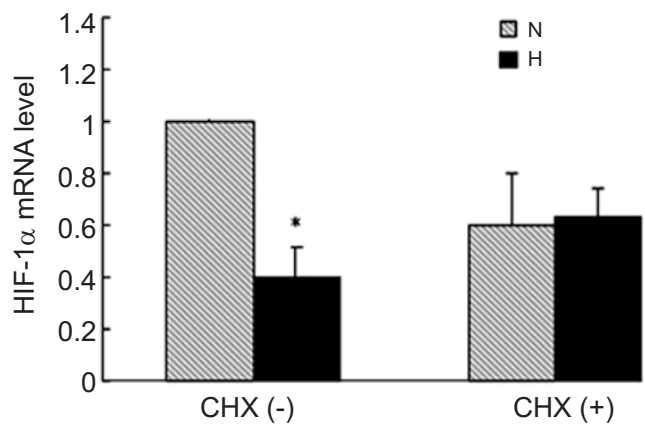

Figure 8 Effects of inhibition of ongoing protein synthesis on HIF-3 $\alpha$ (A) and HIF-1 $\alpha$ (B) mRNA levels in A549 cells. Cells were treated with cycloheximide $(\mathrm{CHX})$, immediately followed by a 6 -h exposure to normoxia $\left(21 \% \mathrm{O}_{2}\right)$ or hypoxia $\left(1 \% \mathrm{O}_{2}\right)$. Value determined at normoxia without CHX was set at 1 . Data are presented as mean \pm S.D. of four different experiments. ${ }^{*} P<0.01 \mathrm{vs}$. $21 \%$ $\mathrm{O}_{2}$, indicating a significant interaction between the $\mathrm{O}_{2}$ concentration and cycloheximide treatment.

mouse (mHIF-3 $\alpha$ ) in 1998 [19]. The human homologue of the mHIF-3 $\alpha$ (hHIF-3 $\alpha$ ) was isolated later and revealed high homology to hHIF-1 $\alpha$ and $-2 \alpha$ [31], which raised the possibility that this might also be involved in adaptive response to changes in oxygen tension. The initial reports showed that in the presence of ARNT, HIF-3 $\alpha$ can form an HRE-binding complex, and that HIF- $3 \alpha$ can alter transcription driven by DNA sequences known to respond to hypoxia [19]. To date, expression has only been studied at the mRNA level of whole-organ homogenates [24, 31]. These studies emphasized organ expression in adult rat, although different human tissues including lung were shown to express HIF-3 $\alpha$ mRNA [32, 33, 34].

This study demonstrates that when cells were exposed to $1 \%$ oxygen for $2 \mathrm{~h}$, a major increase in HIF- $3 \alpha$ and HIF$1 \alpha$ protein was observed, whereas HIF-1 $\alpha$ protein levels decreased from 8 to $16 \mathrm{~h}$. In addition to the decrease in HIF-1 $\alpha$ protein, hypoxia also induced a decrease in HIF-1 $\alpha$ mRNA. These observations in agreement with some previous reports showing that HIF- $1 \alpha$ protein and mRNA levels decreased during sustained hypoxia stimulation in alveolar epithelial cells and many other cell lines [20, 21, 23, 35]. On the other hand, the protein levels HIF-3 $\alpha$ exposed to hypoxia appear to have peaked over 8-16 h, while the mRNA levels peaked from $4 \mathrm{~h}$ to $16 \mathrm{~h}$. One possible explanation for such a discrepancy between mRNA and protein levels is that an inducible expression of HIF-3 $\alpha$ protein by hypoxia is regulated at the protein level as well as at the mRNA levels. This view is supported by a recent study in which HIF-3 $\alpha$ protein and mRNA levels were increased by 2-h hypoxia in rat lung and other organs [24]. The acute hypoxic induction of HIF- $1 \alpha$ and HIF-3 $\alpha$ proteins occurred without change in mRNA abundance. It is consistent with post-translational regulation of HIF- $\alpha$ through an increase in protein stability as reported in many cell lines [36, 37, 38]. Thus, the acute regulation of HIF- $3 \alpha$ subunits also mainly occurs through changes in protein stability. Our data suggest that the stabilization of HIF- $\alpha$ protein precedes an increase in HIF- $\alpha$ transcription. The induction in HIF- $3 \alpha$ and HIF- $1 \alpha$ mRNA in A549 cells in response to hypoxia indicates that the regulatory response of HIF- $\alpha$ may also occur at the mRNA level, which is consistent with the results obtained in in vivo experiments showing mRNA of HIF- $3 \alpha$ and HIF- $1 \alpha$ was predominantly expressed in the perivenous zone of the liver [32]. High steady-state mRNA levels of HIF-3 $\alpha$ were achieved in alveolar epithelial cells during sustained hypoxia. This finding supports earlier results which showed the abundantly expressed levels of HIF- $3 \alpha$ mRNA in human pulmonary artery cells during hypoxia $\left(1 \% \mathrm{O}_{2}, 24 \mathrm{~h}\right)$ [39]. In previous studies, we demonstrated that HIF- $1 \alpha$ mRNA and protein levels decreased in rat pulmonary artery cells during sustained hypoxia [40], thereby suggesting HIF-3 $\alpha$ played an important role in lung responding to hypoxic damage.

It should be noted that the hHIF-3 $\alpha$ has at least six alternatively spliced variants hHIF-3 $\alpha 1-6$ [33]. The antibody was raised against residues 367-385 of hHIF-3 $\alpha 1$, which encodes a 668 amino acid protein that contains a single $\mathrm{N}$-terminal transactivation domain (NAD) like hHIF-1 $\alpha$ and hHIF- $2 \alpha$, but it does not contain a C-terminal transactivation domain (CAD) [31]. The functional properties of HIF-3 $\alpha$ are still unknown. Heidbreder et al [24] suggested that HIF-3 $\alpha$ may contribute to protection during early periods of hypoxia and/or moderate hypoxia. In contrast, HIF-1 $\alpha$ may confer protection against severe and/or prolonged hypoxia $[3,24]$. Our experiments did not find that 
activation of HIF-3 $\alpha$ by hypoxia was transient. Instead, we found it was a long-lasting effect. HIF-3 $\alpha$ was upregulated by severe and/or sustained hypoxia, while HIF-1 $\alpha$ levels decreased. The controversy between our results and others may have arisen because of 1) the use of different experimental model (animals vs. cell culture); or 2) the hypoxia protocol they used was either not sufficiently severe or the selected period was too short to induce any visible quantity changes in HIF- $1 \alpha$ mRNA.

The trans-regulation between HIF- $3 \alpha$ and HIF- $1 \alpha$ was suggested by Makino et al [41], who demonstrated that an alternatively spliced variant of mHIF- $3 \alpha$ was a dominantnegative regulator of mouse HIF- $1 \alpha$. Recently, Marynard et $a l$. [33] found hIPAS, which they named hHIF-3 $\alpha 2$. Despite no direct evidence documenting that HIF-1 $\alpha$ triggers transcriptional up-regulation of HIF- $3 \alpha$, cumulative evidence is available to suggest that HIF-3 $\alpha$ down-regulates HIF- $1 \alpha$ and vice versa. Hara et al. [31] suggested a presence of the competition between HIF- $1 \alpha$ and HIF- $3 \alpha$ for recruitment of the common factor ARNT, and reporter gene analysis showed that hHIF-3 $\alpha 1$ suppressed HIF-1-mediated gene expression. It was reported that HIF-3 $\alpha$ was targeted for pVHL-dependent ubiquitination, whereas HIF- $1 \alpha$ contains structural elements inhibiting ubiquitination [42]. In addition to providing comparative data on regulation of HIF-3 $\alpha$ and HIF- $1 \alpha$, these experiments also offer some new insights into the underlying regulatory mechanisms. DRB experiments and mRNA half-life analysis suggest that the fall in HIF- $1 \alpha$ mRNA levels during sustained hypoxia is related mainly to decreased mRNA stability and the hypoxiainduced HIF-3 $\alpha$ mRNA increase is due to transcriptional activation rather than to a change in mRNA stability.

Nevertheless, our study also demonstrates that induction of HIF- $3 \alpha$ and HIF- $1 \alpha$ showed very similar characteristics of regulation in A549 cells. Both proteins showed a similar induction after exposure to different $\mathrm{O}_{2}$ concentration. Both molecules accumulated following exposure of normoxic cells to cobalt chloride and desferrioxamine. Previous results reported mitochondrial reactive oxygen species inhibitors such as DPI, rotenone and myxothiazol dramatically reduced hypoxia-induced HIF- $1 \alpha$ accumulation and basal activity [21, 43]. In the present study, we found that all the three radical scavengers partially abolished the basal and hypoxic induction of HIF-3 $\alpha$ and HIF- $1 \alpha$ protein. These results further establish the crucial role of mitochondria in the complex process of oxygen sensing and agree with the hypothesis that HIF- $3 \alpha$ protein stabilization also requires, at least, in part, a function electron transport chain. Thus not only do both molecules respond to hypoxia, but it appears that the same, or strikingly similar, oxygen-sensing and probably signal transduction mechanisms regulate the abundance of both transcription factors.
Collectively, our study characterized HIF-3 $\alpha$ as an inducible component of HIF system in alveolar epithelial cells, which is rapidly activated both at the mRNA and protein levels by hypoxia. The differential expression pattern between HIF- $3 \alpha$ and HIF- $1 \alpha$ observed in this study implies HIF-3 $\alpha$ is complementary rather than redundant to HIF- $1 \alpha$ in protection against hypoxic damage in alveolar epithelial cells. Although the oxygen-sensing mechanism involving oxygen-dependent hydroxylation of the HIF- $\alpha$ subunits is probably a universal mechanism in cells and highly conserved during evolution, additional regulatory steps appear to determine which of the alternative subunits is induced. It will be important to establish the expression pattern of HIF- $\alpha$ in vivo and whether they can convey target gene specificity. The answers to such questions should provide new insights into hypoxic adaptation as well as provide a platform for new pharmacologic approaches to hypoxia related diseases.

\section{Acknowledgement}

The authors are extremely grateful to Prof Jing-yuan Fang of Shanghai Institute of Digestive Disease for excellent technical assistance.

\section{Reference}

1 Bergeron M, Yu AY, Solway KE, Semenza GL, Sharp FR. Induction of hypoxia-inducible factor-1 (HIF-1) and its target genes following focal ischaemia in rat brain. Eur J Neurosci 1999; 11:4159-4170

2 Gross ML, Adamczak M, Amann K, Ritz E. Mediators of inflammatory and ischemic renal damage: the role of neoangiogenesis. J Nephrol 2005; 18:513-520

3 Kiang JG, Bowman PD, Wu BW, et al. Geldanamycin treatment inhibits hemorrhage-induced increases in KLF6 and iNOS expression in unresuscitated mouse organs: role of inducible HSP70. J Appl Physiol. 2004; 97:564-569.

4 Zhong H, De Marzo AM, Laughner E, et al. Overexpression of hypoxia-inducible factor 1alpha in common human cancers and their metastases. Cancer Res 1999; 59:5830-5835

5 Guillemin K, Krasnow MA. The hypoxic response: huffing and HIFing. Cell 1997; 89:9-12.

6 Semenza GL. HIF-1: mediator of physiological and pathophysiological responses to hypoxia. J Appl Physiol 2000; 88:14741480 .

7 Wang GL, Jiang BH, Rue EA,Semenza GL. Hypoxia-inducible factor 1 is a basic-helix-loop-helix-PAS heterodimer regulated by cellular O2 tension. Proc Natl Acad Sci U S A 1995; 92:55105514

8 Semenza GL. Regulation of mammalian O2 homeostasis by hypoxia-inducible factor 1. Annu Rev Cell Dev Biol 1999; 15:551-578

9 Jiang BH, Zheng JZ, Leung SW, Roe R, Semenza GL. Transactivation and inhibitory domains of hypoxia-inducible factor 1alpha. Modulation of transcriptional activity by oxygen tension. 
J Biol Chem 1997; 272:19253-19260.

10 Jiang BH, Semenza GL, Bauer C, Marti HH. Hypoxia-inducible factor 1 levels vary exponentially over a physiologically relevant range of $\mathrm{O}_{2}$ tension. Am J Physiol 1996; 271:C1172-C1180.

11 Salceda S, Caro J. Hypoxia-inducible factor 1alpha (HIF-1alpha) protein is rapidly degraded by the ubiquitin-proteasome system under normoxic conditions. Its stabilization by hypoxia depends on redox-induced changes. J Biol Chem 1997; 272: $22642-$ 22647.

12 Huang LE, Arany Z, Livingston DM, Bunn HF. Activation of hypoxia-inducible transcription factor depends primarily upon redox-sensitive stabilization of its alpha subunit. J Biol Chem 1996; 271:32253-32259.

13 Semenza GL, Wang G L. A nuclear factor induced by hypoxia via de novo protein synthesis binds to the human erythropoietin gene enhancer at a site required for transcriptional activation. Mol Cell Biol 1992; 12:5447-5454.

14 Liu Y, Cox SR, Morita T, Kourembanas S. Hypoxia regulates vascular endothelial growth factor gene expression in endothelial cells. Identification of a 5' enhancer. Circ Res 1995; 77: 638643.

15 Melillo G, Musso T, Sica A, et al. A hypoxia-responsive element mediates a novel pathway of activation of the inducible nitric oxide synthase promoter. J Exp Med 1995; 182:1683-1693.

16 Lee PJ, Jiang BH, Chin BY, et al. Hypoxia-inducible factor-1 mediates transcriptional activation of the heme oxygenase-1 gene in response to hypoxia. J Biol Chem 1997; 272:5375-5381.

17 Bruick RK. Oxygen sensing in the hypoxic response pathway: regulation of the hypoxia-inducible transcription factor. Genes Dev 2003; 17:2614-2623.

18 Tian H, McKnight SL, Russell DW. Endothelial PAS domain protein 1 (EPAS1), a transcription factor selectively expressed in endothelial cells. Genes Dev 1997; 11:72-82.

$19 \mathrm{Gu}$ YZ, Moran SM, Hogenesch JB, Wartman , Bradfield CA. Molecular characterization and chromosomal localization of a third alpha-class hypoxia inducible factor subunit, HIF3alpha. Gene Expr 1998; 7:205-213.

20 Sato M ,Tanaka T, Maeno T, et al. Inducible expression of endothelial PAS domain protein-1 by hypoxia in human lung adenocarcinoma A549 cells. Role of Src family kinases-dependent pathway. Am J Respir Cell Mol Biol 2002; 26:127-134.

21 Uchida T, Rossignol F, Matthay MA, et al. Prolonged hypoxia differentially regulates hypoxia-inducible factor (HIF)-1alpha and HIF-2alpha expression in lung epithelial cells: implication of natural antisense HIF-1 alpha. J Biol Chem 2004; 279:1487114878 .

22 Wiesener MS, Jurgensen JS, Rosenberger C, et al. Widespread hypoxia-inducible expression of HIF-2alpha in distinct cell populations of different organs. FASEB J 2003; 17:271-273.

23 Wiesener MS, Turley H, Allen WE, et al. Induction of endothelial PAS domain protein-1 by hypoxia:characterization and comparison with hypoxia-inducible factor-1alpha. Blood 1998; 92:2260-2268.

24 Heidbreder M, Frohlich F, Johren O, et al. Hypoxia rapidly activates HIF-3alpha mRNA expression. FASEB J 2003; 17:15411543.

25 Yoshida T, Kuwahara M, Maita K, Harada T. Immunohistochemical study on hypoxia in spontaneous polycystic liver and kidney disease in rats. Exp Toxicol Pathol 2001; 53:123-128.
26 Koyama S, Sato E, Tsukadaira A, et al. Vascular endothelial growth factor mRNA and protein expression in airway epithelial cell lines in vitro. Eur Respir J 2002; 20:1449-1456.

27 Ouiddir A, Planes C, Fernandes I, VanHesse A, Clerici C. Hypoxia upregulates activity and expression of the glucose transporter GLUT1 in alveolar epithelial cells. Am J Respir Cell Mol Biol 1999; 21:710-718.

28 Pallet N, Thervet E, Le Corre D, et al. Rapamycin inhibits human renal epithelial cell proliferation: effect on cyclin D3 mRNA expression and stability. Kidney Int 2005; 67:2422-2433.

29 Yague E, Armesilla AL, Harrison G, et al. P-glycoprotein (MDR1) expression in leukemic cells is regulated at two distinct steps, mRNA stabilization and translational initiation. J Biol Chem 2003; 278:10344-10352.

30 Pham I, Uchida T, Planes C, et al. Hypoxia upregulates VEGF expression in alveolar epithelial cells in vitro and in vivo. Am J Physiol Lung Cell Mol Physiol. 2002; 283:L1133-1142.

31 Hara S, Hamada J, Kobayashi C, Kondo Y, Imura N. Expression and characterization of hypoxia-inducible factor (HIF)-3alpha in human kidney: suppression of HIF-mediated gene expression by HIF-3alpha. Biochem Biophys Res Commun 2001; 287:808813.

32 Kietzmann T, Cornesse Y, Brechtel K, Modaressi S, Jungermann K. Perivenous expression of the mRNA of the three hypoxiainducible factor alpha-subunits, HIF1alpha, HIF2alpha and HIF3alpha, in rat liver. Biochem J 2001; 354:531-537.

33 Maynard MA, Qi H, Chung J, et al. Multiple splice variants of the human HIF-3 alpha locus are targets of the von Hippel-Lindau E3 ubiquitin ligase complex. J Biol Chem 2003; 278:11032-11040.

34 Hirsila M, Koivunen P, Gunzler V, Kivirikko KI, Myllyharju J. Characterization of the human prolyl 4-hydroxylases that modify the hypoxia-inducible factor. J Biol Chem 2003; 278:3077230780

35 Graven KK, Bellur D, Klahn BD, Lowrey SL, Amberger E. HIF2alpha regulates glyceraldehyde-3-phosphate dehydrogenase expression in endothelial cells. Biochim Biophys Acta 2003; 15:10-18.

36 Wenger RH, Kvietikova I, Rolfs A, Gassmann M, Marti HH. Hypoxia-inducible factor-1 alpha is regulated at the post-mRNA level. Kidney Int 1997; 51:560-563.

37 Katschinski DM, Le L, Schindler SG, et al. Interaction of the PAS B domain with HSP90 accelerates hypoxia-inducible factor1alpha stabilization. Cell Physiol Biochem 2004; 14:351-360.

38 Masson N, Ratcliffe PJ. HIF prolyl and asparaginyl hydroxylases in the biological response to intracellular $\mathrm{O}_{2}$ levels. J Cell Sci 2003; 116:3041-3049.

39 Rose F, Grimminger F, Appel J, et al. Hypoxic pulmonary artery fibroblasts trigger proliferation of vascular smooth muscle cells: role of hypoxia-inducible transcription factors. FASEB J 2002; 16:1660-1661.

40 Li QF, Dai AG. Hypoxia inducible factor-1 alpha correlates the expression of heme oxygenase 1 gene in pulmonary arteries of rat with hypoxia-induced pulmonary hypertension. Acta Biochim Biophys Sin 2004; 36:133-140.

41 Makino Y, Cao R, Svensson K, et al. Inhibitory PAS domain protein is a negative regulator of hypoxia-inducible gene expression. Nature 2001; 29:550-554.

42 Ohh M, Park CW, Ivan M, et al. Ubiquitination of hypoxia-in- 
ducible factor requires direct binding to the beta-domain of the von Hippel-Lindau protein. Nat Cell Biol 2000; 2:423-427.

43 Agani FH, Pichiule P, Chavez JC, LaManna JC. The role of mi- tochondria in the regulation of hypoxia-inducible factor 1 expression during hypoxia. J Biol Chem 2000; 275:35863-35867.

Edited by Juliann G Kiang 